\title{
Development of Arabic Language Lifelong Learning (A3L) Tutorial Platform Using WhatsApp Mobile Application
}

\author{
Nurkhamimi Zainuddin1, Noor Saazai Mat Saad1, Haliza Harun1, Harwati Hashim²* \\ ${ }^{1}$ Faculty of Major Language Studies, Universiti Sains Islam Malaysia, Bandar Baru Nilai, Malaysia \\ ${ }^{2}$ Faculty of Education, Universiti Kebangsaan Malaysia, Bangi, Malaysia \\ Email: ^harwati@ukm.edu.my
}

How to cite this paper: Zainuddin, N., Saad, N. S. M., Harun, H., \& Hashim, H. (2020). Development of Arabic Language Lifelong Learning (A3L) Tutorial Platform Using WhatsApp Mobile Application. Creative Education, 11, 452-467.

https://doi.org/10.4236/ce.2020.114033

Received: March 1, 2020

Accepted: April 5, 2020

Published: April 8, 2020

Copyright $\odot 2020$ by author(s) and Scientific Research Publishing Inc. This work is licensed under the Creative Commons Attribution International License (CC BY 4.0).

http://creativecommons.org/licenses/by/4.0/

\begin{abstract}
This study examined the use of WhatsApp mobile application as a tutorial platform for Arabic language lifelong learning (A3L) at the Universiti Sains Islam Malaysia (USIM). An exploratory research design was adopted and the purposive sampling technique was used in selecting participants for the study. Specifically, the study comprises 40 USIM A3L learners. The WhatsApp mobile application was used as a tutorial delivery tool for the learners. Two research questions were raised and analyzed qualitatively. The result of the analysis indicated that WhatsApp mobile application could be used as tutorial delivery tool for $\mathrm{A} 3 \mathrm{~L}$ following the prescribed steps and procedures. Twelve Arabic lessons were learned which include contents for learners, quizzes, feedbacks and learner supports. Based on the findings, it was recommended that researchers need to extensively respond to the growing need of a body of research in this area, especially building models and strategies that work for the use of social media for the improvement of A3L delivery. Additionally, the A3L facilitators should be equipped with the skills of using mobile technologies, particularly the social media for A3L enhancement.
\end{abstract}

\section{Keywords}

Arabic Language, Lifelong Learning, Tutorial, Delivery Tool, Mobile Learning

\section{Introduction}

Today, educational mobile technology is frequently used in online instruction in universities worldwide (Jimoyiannis, Tsiotakis, Roussinos, \& Siorenta, 2013; Hashim, Yunus, \& Embi, 2018). It offers students increased choices and opportunities in the context of online instruction. Online courses that incorporate 
mobile technologies are becoming a more frequent component in universities, and the number of web-based mobile courses has increased (Inan, Flores, \& Grant, 2010). The information and communication technologies shared between online students through social interactions on mobile tools promote opportunities for online cooperation and collaboration (Barhoumi \& Rossi, 2013). Mobile educational technologies provide online learners with opportunities to communicate and share knowledge (Nelson, Christopher, \& Mims, 2009) without worrying of the distance (Zaki \& Yunus, 2015). Moreover, the integration of mobile technology gives the opportunity for the learners to access various useful materials and try different activities (Azli, Shah, \& Mohamad, 2018).

Using and integrating some technological devices may motivate students as well as teachers to do their traditional jobs in different and attractive ways. Prensky (2001) mentioned that students these days are all native speakers of digital language of computers and the internet. Undeniably, these learners are not just digital natives but also mobile natives (Harun, Abdullah, \& Zainuddin, 2018). They adopt new instructional technologies which include mobile technology in their learning and constructing knowledge. Thus, it is crucial to redesign learning as to cater to their needs and learning styles.

Such technological devices may make the educational environment differ from the traditional way that concentrates completely on the classroom in giving information to learners to a new way of learning outside the classroom. Besides, they provide learners and instructors the opportunity to learn and communicate with others at anytime and anywhere (Crescente \& Lee, 2011). To add, studies have shown that students are able to learn well via mobile devices (e.g. Ismail, Nordin, Yunus, Norman, \& Rahim, 2017). Due to that, there is a need to investigate the use of various mobile applications for the purpose of teaching and learning. This study examined the use of WhatsApp mobile application as a tutorial platform for Arabic language lifelong learning (A3L) at the Universiti Sains Islam Malaysia (USIM). The aims and objectives of this study are: 1) to explore the steps and procedures in developing tutorial platform for Arabic A3L using WhatsApp mobile application; and, 2) to study what are the USIM A3L students' view on the use of WhatsApp mobile application as an Arabic language lifelong learning tutorial platform to stimulate interaction with the instructor, peers and instructional content.

\section{Literature Review}

\subsection{Interaction and Mobile Technology}

Since interaction plays a significant role in enhancing the amount of learning as previously stated, there have been a variety of studies that explored the impact of mobile technology on influencing instructional interaction. For example, Davis (2003) indicated that using mobile technology in the classroom enhanced the instructional interaction through allowing students to respond to the teacher's questions instantly and anonymously. He also reported that students were more 
willing to take risks in exploring answers, because of the anonymity involved. More in recent studies, Gong and Wallace (2012) report that students in their study provide a number of potentials regarding the use of mobile technology including: enhancing communication with the instructor, simplifying communication, providing a motivating learning experience, and enabling more convenient studies.

From a different perspective, Bere (2012) compared the use of WhatsApp social networking and the Blackboard LMS as ubiquitous tools for academic collaboration. A comparison was made using students' experience to deduce a popular ubiquitous learning platform for the participants. The results indicated that most students prefer the WhatsApp social networking compared to learner management systems. Free access, edutainment and multitasking are among the aspects that made WhatsApp a preferred learning platform.

The previous literature review clearly suggests that mobile technology seemed to be an effective aid that instructors might use to enhance students' interaction. The fast growth of new generation of mobile devices as well as progression in wireless technology has intensified the great potential of mobile learning in becoming an effective tool for learning (Hussin, Manap, Amir, \& Krish, 2012; Zainuddin \& Idrus, 2017).

On the other hand, other researchers expressed concerns regarding the impact of integrating technology on interaction and students' engagement (Rahman, Sahrir, Zainuddin, \& Khafidz, 2018; Liu, Chung, Cen, \& Liu, 2009; Şerbănescu, 2010). Şerbănescu (2010) argues that new technology innovations may decrease the direct interaction and immediate feedback between students and professors. Liu et al. (2009) state that the screen on handheld devices is designed for individual-user mobile applications and may constrain interaction among group learners.

\subsection{WhatsApp as a Lifelong Learning Tutorial Platform}

The development of technology is getting faster. Mobile technologies that many people know are usually associated with devices that are portable. Sharples (2000) states that technologies can be used in learning as: 1) an intelligent tutor system, 2) simulators and learning tools as well as pedagogy agents, 3) system devices and resources, 4) communication devices, and 5) simulation classrooms.

The modification of many mobile applications has given the new inspiration for all learners to be easer gaining the information of knowledge and science. Online instructors and tutors are using mobile applications in universities around the world.

One of mobile applications used for online tutorial is "WhatsApp messenger". It is a mobile application that employs users' existing internet data plan to help them network with others (WhatsApp, 2010). It is used for sending and receiving messages, video and audio messages. It has spread mostly among young people who are students and use it as an entertainment, synchronous discussion and learning tool. They largely depend on it to know a lot of news around the 
world. Besides, the application may help them in their learning through exchanging information needed in language learning since it is used by most of the students. It provides access to learning resources when teachers and students are separated by time and distance (Honeyman \& Miller, 1993).

The general benefits of using WhatsApp mobile application according to Bere (2012) in the online tutorial environment are as follows:

- WhatsApp is a free mobile application that is easy to use.

- WhatsApp mobile application facilitates online collaboration and cooperation between online students connected from school or home in a blended mobile lecture.

- Groups connected to WhatsApp mobile application can share learning objects easily through comments, texting and messaging. Discussions are related to the course content taught $100 \%$ in-class.

- WhatsApp mobile application provides students with the ability to create a class publication and thereby publish their work in the group.

- WhatsApp mobile application provides offline messaging. It means that all messages transmitted when the device is off or when it is located outside the coverage area are automatically saved and retrievable when network coverage is restored or when the device is turned on.

- WhatsApp mobile application works via phone numbers and integrates with users' address books, thus there is no need to memorize usernames or passwords.

In this context, the key question to answer is thus: how do we use mobile technology applications such as WhatsApp for lifelong learning students? Is it better to use mobile technology to achieve cooperative and collaborative activities in a blended course? In a study by Preston et al. (2010), nearly $70 \%$ of the students stated that they learn equally well from online lectures as in-class lectures.

Additionally, non-traditional students need an effective blended online learning strategy to pursue blended courses. For these reasons, the present study is conducted with A3L students to explore the effectiveness of the blended scenario in a course using the WhatsApp mobile application.

\subsection{A3L Learning Materials}

The present case study was conducted for A3L class at the Universiti Sains Islam Malaysia (USIM). An online tutorial platform supported by WhatsApp application was created as an additional component to A3L course over twelve weeks. The steps and procedures in developing tutorial platform for A3L using WhatsApp mobile application are as follows:

- Planning-A3L course team outline structure, instructions, preparing topics, activities and assessment.

- Storyboarding - storyboards for all topics were designed and developed using Power Point and shared with course instructors through A3L Google Drive. The content validation done by subject matter experts. The topics are indi- 
cated in Table 1.

- Production-All notes from each topic were converted into JPEG format outputs (as illustrated in Figures 1-12) and tested on various PCs, IOS and Android gadgets.

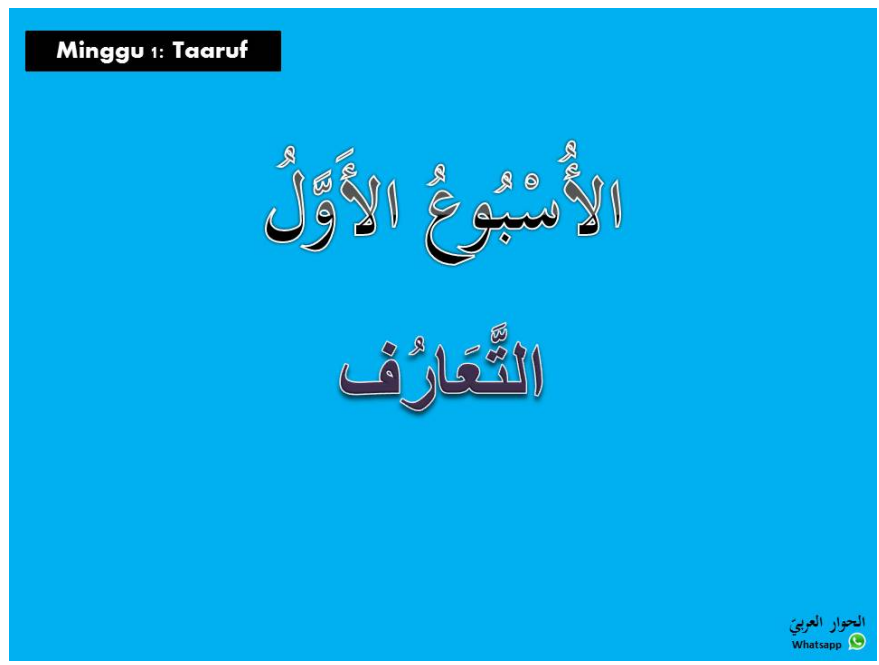

Figure 1. Ta'aruf.

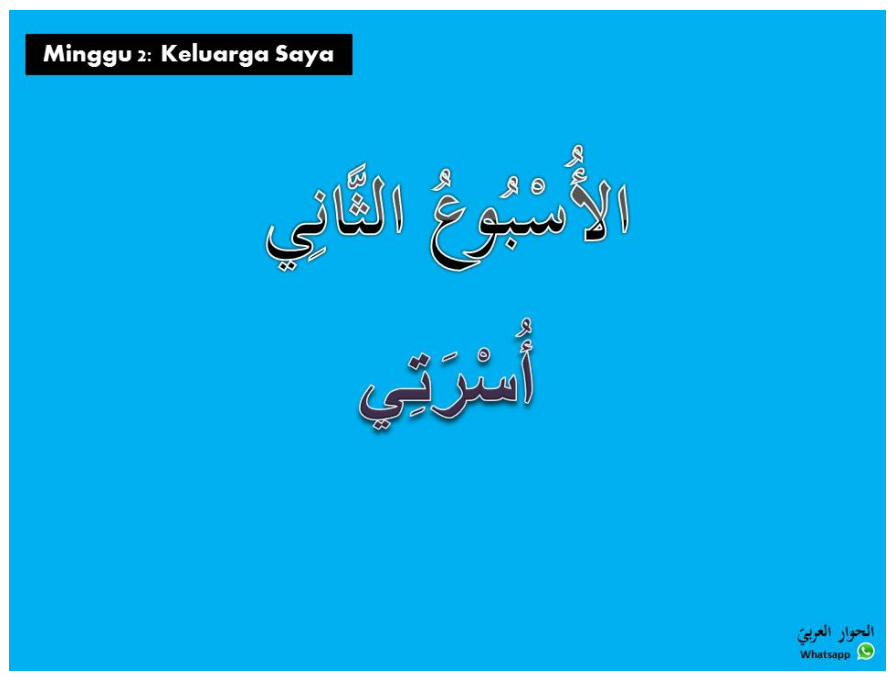

Figure 2. My family.

Table 1. 12 topics in A3L course.

\begin{tabular}{|c|c|c|c|}
\hline Week & Topic & Week & Topic \\
\hline 1 & Ta’aruf - التعارف & 7 & My ibadah - عبادتي \\
\hline 2 & أسرني - My family & 8 & في المركز التجاري - At the mall \\
\hline 3 & Time, days and months - الساعات، الأيام والثهور & 9 & يوم العطلة - Holiday ب \\
\hline 4 & My occupation - مهنتي & 10 & Festivals in Islam - الأعياد في الإسلام \\
\hline 5 & My hobby - هوايتي & 11 & Umrah and Hajj - العمرة والحج \\
\hline 6 & Food and beverages - الطعام و الثر اب & 12 & I love Arabic language - أحب اللغة العربية \\
\hline
\end{tabular}




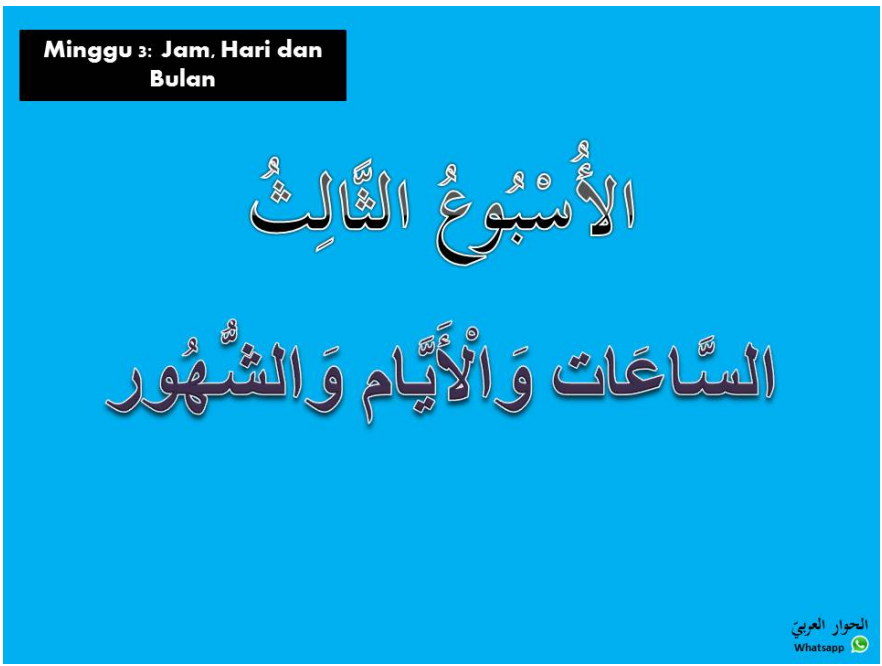

Figure 3. Time, days and months.

\section{Minggu 4: Pekerjaan Saya}
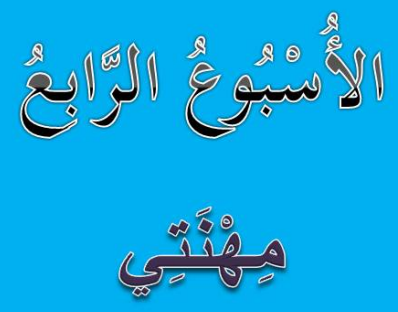

Figure 4. My occupation.

\section{Minggu 5: Hobi Saya}
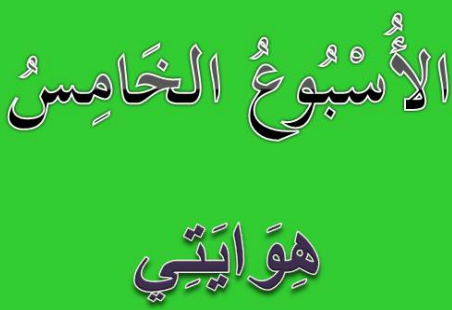

Figure 5. My hobby. 


\section{Minggu s: Makanan dan}

Minuman

Figure 6. Food and beverages

\section{Minggu 7: lbadahku}
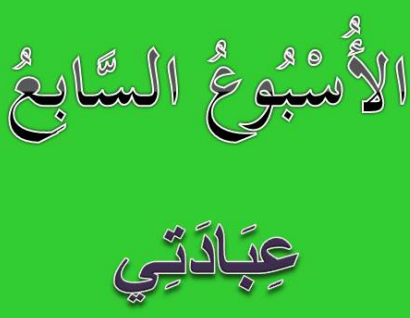

Figure 7. My ibadah.

Minggu \&: Di Pusat

Membeli Belah
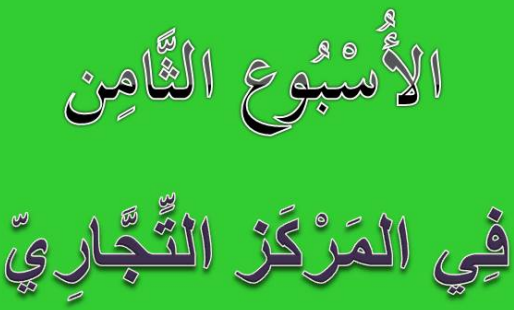

Figure 8. At the mall. 


\section{Minggu 9: Percutian Saya}
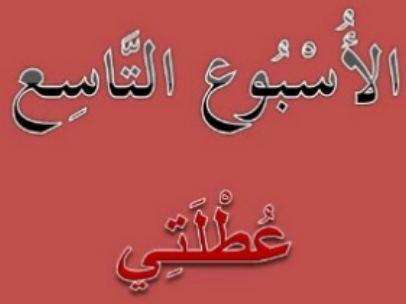

Figure 9. Holiday.

\section{Minggu 10: Perayaan}

Dalam Islam
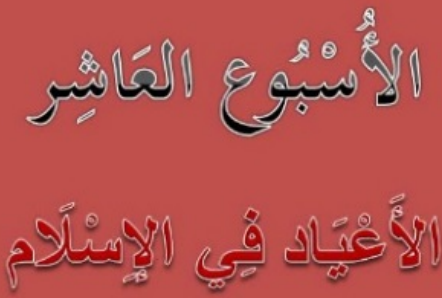

Figure 10. Festivals in Islam.

\section{Minggu 11: Umrah dar}

Haji
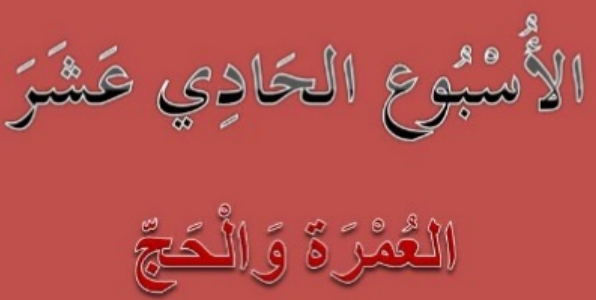

Figure 11. Umrah and Hajj. 


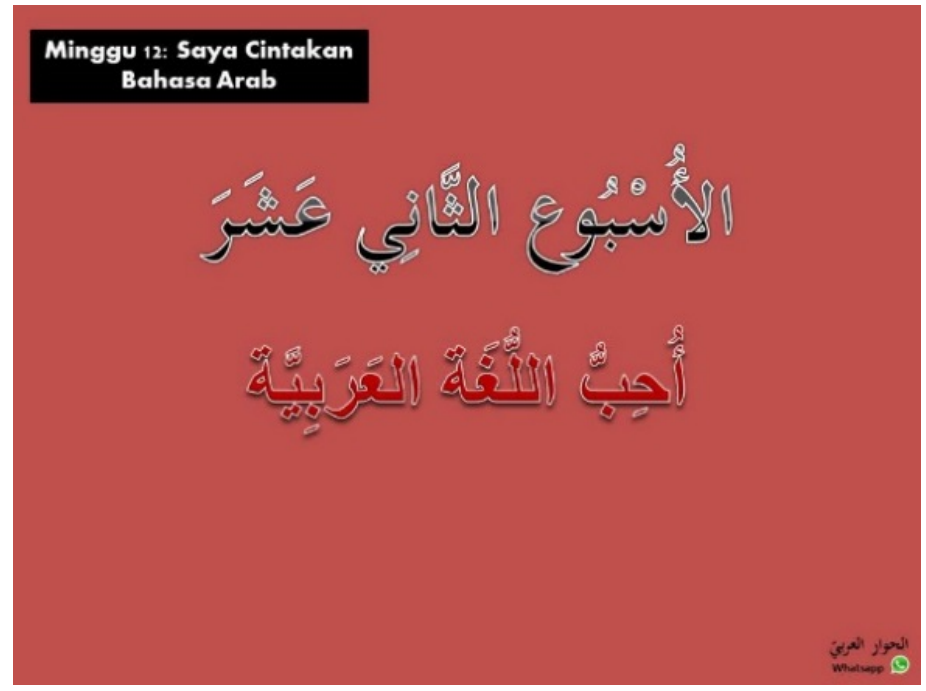

Figure 12. I love Arabic language.

- Implementation-After face to face class, A3L course team will post the notes in the A3L WhatsApp group. This WhatsApp group was mainly adapted for allowing A3L students to connect with others and academically collaborate through posting educational and meaningful content related to Arabic language, supporting their posts with resources (videos, audios, pictures, websites links etc.), discussing course content, asking questions, responding to questions, and commenting on daily lectures.

- Review-Gathering on-going feedback from A3L students and course instructors.

In order to encourage USIM A3L students to engage in productive interactions and in-depth discussions, they were instructed to meet specific posting requirements and evaluation criteria.

The criteria included the following:

- Contributions should be reflections of A3L course content.

- Contributions should include new ideas, reflections, opinions and critical thinking, not mere description or summary.

- Each A3L student is expected to post at least four responses per week.

- Replying to the instructors and peers' questions should be within 24 hours.

The main purpose of the virtual discussions was to facilitate a productive social interaction by empowering USIM A3L students and encouraging them to take on the role of critic and inquirer (Kalelioglu \& Gülbahar, 2014). The course instructor's role included responding to students' questions, giving feedback, and evaluating students' contributions based on the provided criteria. The investigation covers 40 participants who were registered in a section of A3L course organized by the Division of Lifelong Learning, GOAL ITQAN, USIM during the first semester of 2016/2017. All postings including ideas, thoughts, responses, comments, audio and video clips and threads were available to the USIM A3L students to be viewed throughout the semester. 


\section{Methodology}

In this study, 40 USIM A3L learners were involved in the data collection procedure which is further explained in the following sections.

\subsection{Data Collection and Procedures}

Two different sources of data were used to collect the information needed related to the satisfaction level of USIM A3L students in using WhatsApp mobile application as an $\mathrm{A} 3 \mathrm{~L}$ tutorial platform. They were semi-structured interviews and analysis of participants' posts on the A3L WhatsApp group. Interviews were conducted to obtain in-depth perspectives, along with personal stories and contexts of the USIM A3L students. The interview questions dealt with the following areas of inquiry:

- Individual views of WhatsApp as a tool to foster interaction (student-student, student instructor, and student-content).

- Successful stories in integrating WhatsApp mobile application to enhance interaction and learning among USIM A3L students.

- Willing to integrate WhatsApp in future Arabic language classes.

- Individual views regarding the challenges of WhatsApp mobile application integration in the learning process.

The interview questions were reviewed and refereed by a panel of experts to judge their quality and adequacy for answering the research questions. Based on this review process, two questions were added, and two questions were modified according to the panel's comments and suggestions. The researchers also interviewed three USIM A3L students who were not participating in the actual study to ensure that the interview questions were comprehensible and would generate valuable information and an in-depth query. A few questions were modified based on comments raised during the pilot interviews. It is important to note that before conducting the actual interviews, an orientation meeting was held with all participants to explain the purpose of the study, and the data collection details to ensure confidentiality, and to get USIM A3L students' approval to use their comments for scientific research. Each interview lasted for 22 to $49 \mathrm{mi}-$ nutes. The substantive phases of the data collection were audio-taped and transcribed into Malay in which participants communicate. Recording interviews assured having the most complete record of what was said as advised by Hitchcock and Hughes (1995).

The secondary data collection method for this study was collecting participants' posts on the USIM A3L WhatsApp group. Students' posts were used to support the findings of the interviews by identifying what students did and what they valued. Both the interviews transcripts and participants' posts were transferred to a computer file. In addition, index cards were prepared for each question and the data were made ready for further analysis.

\subsection{Data Analysis}

To analyze the data drawn from interviews with 40 USIM A3L students and 
their postings on A3L WhatsApp group, the framework of verbal analysis method developed by Chi (1997) was utilized. According to Chi (1997) there are eight required steps to analyze verbal data. 1) Choosing the sample 2) Choosing the unit size of each sample 3) Choosing or creating the coding scheme 4) Choosing how the coding scheme will be implemented and coding the data 5) Representing the coded data in a way that can be analyzed 6) Analyzing the data 7) Interpreting the analysis 8) Repeating some or all of the steps for greater clarity.

In the present study, the researcher followed this method literally. After gathering and transcribing the study data, it was reduced by doing some preliminary coding on the content of the entire set and then more detailed coding on a selected subset. Later on, the data was segmented into appropriate portions based on semantic features such as ideas, concepts, argument chains and topics of discussion.

Once data was segmented, a coding scheme was developed in which each segment was independently coded according to the study research questions. Implementing coding requires deciding which utterances constitute evidence that they belong to a specific category or can be translated into a specific code. After coding the data, the results were depicted to present the data to the audience and to seek patterns that can be detected in the depicted data. Finally, the perceived patterns in the depicted data were interpreted entirely based on the research questions being asked.

To judge the value of a qualitative study, the internal and external validity were utilized. The internal validity was conducted by using peer debriefing techniques and member checking to validate the descriptions of the data and the interpretations. On the other hand, the external validity was conducted by providing much rich and thick description as possible while addressing all of the diverse aspects of the findings (Merriam, 1998) by utilizing quotes from the interviews.

\section{Findings}

The results of the study are presented based on the questions asked below.

Q1. What are the USIM A3L students' view on the use of WhatsApp mobile application as an Arabic language lifelong learning tutorial platform to stimulate interaction with the instructor, peers and instructional content?

The USIM A3L students were asked to evaluate the impact of WhatsApp mobile application on enhancing the instructional interaction. It includes student-student, student-instructor, and student-content interaction. They were able to select multiple options that applied for them. The results revealed mix views. First, they respondents reported that WhatsApp mobile application had the power to enhance and support student-student interaction. They concluded that WhatsApp mobile application opened a free and convenient channel for communicating, expressing ideas and thoughts, as well as getting help and assistance easily and quickly. This finding was evident in the USIM A3L students' 
typical responses, as shown in Table 2.

In addition, the USIM A3L students expressed that A3L WhatsApp group enhanced interaction with the instructional content. They stated that accessing to an enormous amount of information posted on the platform allowed them to think more deeply before posting their contributions. Table 3 shows some participants' responses regarding the impact of WhatsApp mobile application in enhancing student-content interaction:

Table 2. A3L students' reflection on interaction.

\begin{tabular}{|c|c|c|}
\hline No & A3L Students & Reflections \\
\hline 1 & A3L11 & $\begin{array}{l}\text { I love learning Arabic when it takes an advantage of what we already } \\
\text { have. My smart phone is always in my hand. So it is very easy and } \\
\text { comfortable to get clarifications about some things I missed by } \\
\text { just asking my classmates using the A3L WhatsApp group. What I } \\
\text { need to do is just post my question and wait for variety of answers. }\end{array}$ \\
\hline 2 & A3L13 & $\begin{array}{l}\text { As a lifelong learning student, I used to rely heavily on SMS at night } \\
\text { to contact with my peers to achieve some of my learning purposes. } \\
\text { In A3L course, the instructors provided us with a new source to get } \\
\text { help from classmates whenever and wherever, because I need to } \\
\text { work during daytime. }\end{array}$ \\
\hline 3 & A3L28 & $\begin{array}{l}\text { It is a fabulous and more convenient tool than Google Classroom, } \\
\text { Facebook and Skype. It is always on, and surely you will find some of } \\
\text { your classmates online as well. There are different opportunities to ask } \\
\text { or to discuss with them your interesting course topics. Whats App made } \\
\text { lifelong learning courses more fun, enjoyable and more interactive. }\end{array}$ \\
\hline 4 & A3L36 & $\begin{array}{l}\text { In many cases, I engaged in discussions while I was in the taxi, } \\
\text { bus or in a shopping mall. Learning occurs anywhere and at any time. } \\
\text { There is plenty of space for all A3L students to participate without fear } \\
\text { or shyness. }\end{array}$ \\
\hline
\end{tabular}

Table 3. WhatsApp impact in enhancing student-content interaction.

\begin{tabular}{|c|c|c|}
\hline No & A3L Students & Reflections \\
\hline 1 & A3L5 & $\begin{array}{l}\text { The criteria that the USIM A3L instructor used to assess our } \\
\text { contributions to the WhatsApp group are very strict. Thus, posting a } \\
\text { good answer required a big effort as we need to revise the instructor's } \\
\text { notes, peers' responses and course reading. I believe that this } \\
\text { process positively impacted my learning by making me think } \\
\text { more deeply and critically. }\end{array}$ \\
\hline 2 & A3L7 & $\begin{array}{l}\text { I have learnt many new things while reading posted materials, } \\
\text { for example, reading others'opinions made me think in a different and } \\
\text { more creative way. Like waiting for any new post on my Facebook page, } \\
\text { I'm interested in reading new posts on the USIM A3L WhatsApp group. }\end{array}$ \\
\hline 3 & A3L24 & $\begin{array}{l}\text { In some cases, it took me a lot of time to read, search and think to } \\
\text { respond to some ideas or questions. Furthermore, I had to access } \\
\text { previous discussions on USIM A3L WhatsApp group to review some } \\
\text { ideas before formulating my final answer. It is burdensome, but beneficial. }\end{array}$ \\
\hline 4 & A3L39 & $\begin{array}{l}\text { As an example, there were several small video clips about different } \\
\text { aspect of teaching posted on the USIM A3L Whats App group. } \\
\text { I watched each one several times during my leisure time before my } \\
\text { Arabic lesson presentation assignment. Watching and thinking of these } \\
\text { clips provided me with a clear picture about quality course delivery. } \\
\text { Really, there is no time to waste. }\end{array}$ \\
\hline
\end{tabular}


In regard to student-instructor interaction, the USIM A3L students pointed out that WhatsApp group was valuable in enhancing interaction with the instructor. Table 4 highlighted the significance of using this tool to interact directly with the instructor.

On the contrary, the USIM A3L students reported that WhatsApp group does not help them in improving the interaction. They do mention that they do not have time to read and give response to all posted materials and questions as they think that no one will read it. Some of them prefer to visit the instructor during office hours for face to face session. One student added that WhatsApp mobile application is just a toy for socializing and having fun and it is not meant for learning as it will distract students from learning.

Another important finding of this study is USIM A3L students are willing to use WhatsApp mobile application as an interactive tutorial platform in their future career. They were asked about if they will integrate WhatsApp in their Arabic language teaching classes. The finding of this question reflects the previous findings regarding the impact of WhatsApp mobile application on interaction. USIM A3L students who valued the use of WhatsApp as an interactive tutorial platform reported that they surely will utilize the use of WhatsApp in their other Arabic class. In other words, the participants indicated that they will use WhatsApp mobile application to enhance interaction in their future Arabic classes. Those participants asserted that WhatsApp mobile application helped them to learn in an environment which is full of motivation, fun and opportunity to participate and engage in effective instructional interaction and reflection. Thus, they reported that they will transfer such environment to the other Arabic classes.

\section{Conclusions}

This study revealed that WhatsApp mobile application had the power to enhance lifelong learning USIM A3L learning interaction, mainly student-student interaction in the first place, followed by student-content interaction and student-instructor interaction. The main function of WhatsApp mobile application

Table 4. WhatsApp impact in enhancing student-instructor interaction.

\begin{tabular}{|c|c|c|}
\hline No & A3L Students & Reflections \\
\hline 1 & A3L9 & $\begin{array}{l}\text { Personally, I prefer to ask my instructor over the WhatsApp group } \\
\text { rather than asking him in class. When I post, I have time and } \\
\text { opportunity to think and correct myself before asking my question } \\
\text { or idea without being shy or afraid of wasting class time. }\end{array}$ \\
\hline 2 & A3L25 & $\begin{array}{l}\text { WhatsApp is easier now than visiting the instructor during office hours } \\
\text { or even sending him an email. The question you post will be answered } \\
\text { by the instructor or peers immediately. This lifelong learning tutorial } \\
\text { platform encouraged us to communicate with the instructor and } \\
\text { each other on regular and daily basis. }\end{array}$ \\
\hline 3 & A3L40 & $\begin{array}{l}\text { For lifelong learners like me, if I don't like to write my question, } \\
\text { answer, idea etc, I can send it as an audio or voice note in } \\
\text { WhatsApp group. In this class, things are more possible. }\end{array}$ \\
\hline
\end{tabular}


was providing lifelong learning students with an open and flexible space for communicating, expressing ideas and exchanging information. However, expenses involved in WhatsApp use, distraction to learning, lack of students' commitment for effective participation were identified as the greatest challenges of effective WhatsApp utilization as an Arabic lifelong learning tutorial platform. Based on the findings of this study, a few recommendations were offered that may lead to effective integration of WhatsApp in the learning process:

- Utilizing WhatsApp mobile application as a learning tool to enhance interaction and improve students' learning.

- Providing students with adequate and reliable wireless internet access to enable more equal access on their mobile technologies.

- Providing educators with training programs that focus on the effective integration of new technology application.

- Creating pedagogical strategies that support lifelong learning students' efforts of WhatsApp and other technological applications integration.

- Creating a strategy for WhatsApp integration that explicates regulations of technology use, criteria for the participation and guidelines for evaluating students' contributions.

- Conducting further research that includes larger sample, mix methods, different group of students and different types of WhatsApp activities to validate the findings of the present study.

\section{Conflicts of Interest}

The authors declare no conflicts of interest regarding the publication of this paper.

\section{References}

Azli, W. U. A. W., Shah, P. M., \& Mohamad, M. (2018). Perception on the Usage of Mobile Assisted Language Learning (MALL) in English as a Second Language (ESL) Learning among Vocational College Students. Creative Education, 9, 84-98. https://doi.org/10.4236/ce.2018.91008

Barhoumi, C., \& Rossi, PG. (2013). The Effectiveness of the Instruction-Oriented Hypertext Systems Compared to Direct Instruction in e-Learning Environment. Contemporary Educational Technology, 4, 281-308. https://doi.org/10.30935/cedtech/6109

Bere, A. (2012). A Comparative Study of Student Experiences of Ubiquitous Learning via Mobile Devices and Learner Management Systems at a South African University. In: Proceedings of the 14th Annual Conference on World Wide Web Applications (pp. 4-17). Durban, South Africa: Cape Peninsula University of Technology.

Chi, M. (1997). Quantifying Qualitative Analyses of Verbal Data: A Practical Guide. The Journal of the Learning Sciences, 6, 271-315. https://doi.org/10.1207/s15327809j1s0603_1

Crescente, M. L., \& Lee, D. (2011). Critical Issues of m-Learning: Design Models, Adoption Processes, and Future Trends. Journal of the Chinese Institute of Industrial Engineers, 28, 111-123. https://doi.org/10.1080/10170669.2010.548856

Davis, S. (2003). Observations in Classrooms Using a Network of Handheld Devices. 
Journal of Computer Assisted Learning, 19, 298-307.

https://doi.org/10.1046/j.0266-4909.2003.00031.x

Gong, Z., \& Wallace, J. (2012). A Comparative Analysis of iPad and Other m-Learning Technologies: Exploring Students' View of Adoption, Potentials, and Challenges. Journal of Literacy and Technology, 13, 2-29.

Harun, H., Abdullah, N., \& Zainuddin, N. (2018). Revolutionary Grammar Learning via GLOw@CBI (Grammar Learning Online with Concept Based Instruction). International Journal of Modern Languages and Applied Linguistics, 2, 17-22.

Hashim, H., Yunus, M. M., \& Embi, M. A. (2018). Measuring ESL Learners' Intention for Using Mobile Learning: The Development of Instrument using EFA. Journal of Advance Research in Dynamical \& Control Systems, 1696-1704.

Hitchcock, G., \& Hughes, D. (1995). Research and the Teacher: A Qualitative Introduction to School-Based Research. New York: Routledge Chapman \& Hall.

Honeyman, M., \& Miller, G. (1993). Agriculture Distance Education: A Valid Alternative for Higher Education? In: Proceedings of the 20th Annual National Agricultural Education Research Meeting (pp. 67-73). Islamabad: National Book Foundation.

Hussin, S., Manap, M. R., Amir, Z., \& Krish, P. (2012). Mobile Learning Readiness among Malaysian Students at Higher Learning Institutes. Asian Social Science, 8, 276. https://doi.org/10.5539/ass.v8n12p276

Inan, F. A., Flores, R., \& Grant, M. M. (2010). Perspectives on the Design and Evaluation of Adaptive Web-Based Learning Environments. Contemporary Educational Technology, 1, 148-159. https://doi.org/10.30935/cedtech/5971

Ismail, I. M., Nordin, N. M., Yunus, M. M., Norman, H., \& Rahim, A. A. A. (2017). Self-Directed Learning Style on Performance Based Mobile Learning for Engineering Graphic Course. Man in India, 97, 15-23.

Jimoyiannis, A., Tsiotakis, P., Roussinos, D., \& Siorenta, A. (2013) Preparing Teachers to Integrate Mobile in School Practice: Toward a Framework for Pedagogy 2.0. Australasian Journal of Educational Technology, 29, 248-26. https://doi.org/10.14742/ajet.157

Kalelioglu, F., \& Gülbahar, Y. (2014). The Effect of Instructional Techniques on Critical Thinking and Critical Thinking Dispositions in Online Discussion. Educational Technology \& Society, 17, 248-258.

Liu, C.-C., Chung, C.-W., Cen, N.-S., \& Liu, B.-J. (2009). Analysis of Peer Interaction in Learning Activities with Personal Handhelds and Shared Displays. Journal of Educational Technology \& Society, 12, 127-142.

Merriam, S. (1998). Qualitative Research and Case Study Applications in Education. San Francisco, CA: Jossey-Bass.

Nelson, J., Christopher, A., \& Mims, C. (2009). TPACK and Mobile: Transformation of Teaching and Learning. TechTrends: Linking Research \& Practice to Improve Learning, 53, 80-87. https://doi.org/10.1007/s11528-009-0329-z

Prensky, M. (2001). Digital Natives, Digital Immigrants Part 1. On the Horizon, 9, 1-6. https://doi.org/10.1108/10748120110424816

Preston, G., Phillips, R., Gosper, M., McNeill, M., Woo, K., \& Green, D. (2010). Web-Based Lecture Technologies: Highlighting the Changing Nature of Teaching and Learning. Australasian Journal of Educational Technology, 26, 717-728. https://doi.org/10.14742/ajet.1038

Rahman, A. A., Sahrir, M. S., Zainuddin, N., \& Khafidz, H. A. (2018). An Evaluation of Global Zakat Game (GZG) as Edutainment Board Game in Enhancing Zakat Education in Malaysia. Educational Research and Reviews, 13, 166-172. 


\section{https://doi.org/10.5897/ERR2018.3487}

Şerbănescu, L. (2010). Internet-A New Way of Training. Designing an E-Learning Platforms. Revista tinerilor economişti, (14 spec), 151-158.

Sharples, M. (2000). The Design of Personal Mobile Technologies for Lifelong Learning. Computers \& Education, 34, 177-193. https://doi.org/10.1016/S0360-1315(99)00044-5

WhatsApp (2010). BlackBerry App World.

Zainuddin, N., \& Idrus, R. M. (2017). From TPACK to Learning Buffet: Developing a New Model for Open and Flexible Learning. Saudi Journal of Humanities and Social Sciences, 2, 344-347.

Zaki, A. A., \& Yunus, M. M. (2015). Potential of Mobile Learning in Teaching of ESL Academic Writing. English Language Teaching, 8, 11-19.

https://doi.org/10.5539/elt.v8n6p11 